\title{
THE EFFECTIVENESS OF POCKET BOOK OF HEALTHY SEXUAL BEHAVIOR IN IMPROVING KNOWLEDGE AND ATTITUDE ON PREMARITAL SEXUAL AMONG ADOLESCENTS IN YOGYAKARTA
}

\author{
Sitti Nur Djannah, Isna Wanufika \\ Masters Program in Public Health, Universitas Ahmad Dahlan, Yogyakarta
}

\begin{abstract}
Background: The sexual behavior of adolescents is of importance due to the increasing number of sexually active adolescents globally. While initiation of sexual activity is a part of normal behavior and development, it may also be associated with negative outcomes, if sexual behavior involves engagement in sexual activity at too early an age, or without due attention to the risks involved. This study aimed to examine the effectiveness of the pocket book of healthy sexual behavior in enhancing knowledge and attitude on premarital sex among adolescents.

Subjects and Method: This was a quasi-experiment before and after study with no control group design conducted at YPKK 3 Vocational High School, Sleman, Yogyakarta. A sample of 36 high school students was selected for this study. The independent variable was pocket book of healthy sexual behavior, which was given to the adolescents under study. The dependent variables were knowledge and attitude of premarital sex, which were measured before and after the pocket book intervention. The data were collected by questionnaire and analyzed by a Wilcoxon test.

Results: Knowledge score of premarital sex after the intervention (Mean=10.53; $\mathrm{SD}=1.25)$ was higher than before (Mean=8.33; $\mathrm{SD}=0.83$ ) and it was statistically significant $(\mathrm{p}=0.009)$. Attitude score of premarital sex after intervention (Mean= 48.64; $\mathrm{SD}=2.37)$ was higher than before $(\mathrm{Mean}=45.86 ; \mathrm{SD}=2.66)$ and it was statistically significant $(\mathrm{p}=0.001)$.

Conclusion: Pocket book of healthy sexual behavior is effective to enhance both knowledge and attitude among adolescents.
\end{abstract}

Keywords: knowledge, attitude, premarital sex, pocket book, adolescents

\section{Correspondence:}

Sitti Nur Djannah. Masters Program in Public Health, Universitas Ahmad Dahlan, Yogyakarta. Email: sitti.nurdjannah@ikm.uad.ac.id.

Mobile: 085868180863.

The 4th International Conference on Public Health Best Western Premier Hotel, Solo, Indonesia, August 29-30, 2018 | 168 https://doi.org/10.26911/theicph.2018.02.49 